УАК 552.322.2:553.493 (477.6)

В. В. СУКАЧ, д-р геол. наук, завідувач відділу (Інститут геохімії, мінералогії та рудоутворення ім. М. П. Семененка НАН України), svital@ukr.net, https://orcid.org/0000-0002-4710-7230,

Л. В. ІСАКОВ, д-р геол. наук, старший науковий співробітник (Інститут геохімії, мінералогії та рудоутворення ім. М. П. Семененка НАН України), isakov_l@ukr.net, https://orcid.org/0000-0002-7672-9602,

В. П. БЕЗВИннИй, кандидат геол. наук, головний геолог (ДП “Українська геологічна компанія"), v.bezvynnyi@ukrgeol.com, В. О. ШПИЛЬЧАК, головний геолог (Дніпровська геологічна експедиція ДП“Українська геологічна компанія"), spwas@ukr.net

\title{
ПОШУКИ РОДОВИЩ РІДКІСНИХ МЕТАЛІВ У СХІДНОУКРАЇНСЬКІЙ ПЕГМАТИТОВІЙ ОБЛАСТІ - ВАЖЛИВИЙ СКЛАДНИК ГЕОЛОГОРОЗВІДУВАЛЬНИХ РОБІТ В УКРАЇНІ
}

\author{
PROSPECTING OF RARE METALS IN THE EAST-UKRAINIAN PEGMATITE PROVINCE - \\ IMPORTANT PART OF GEOLOGICAL EXPLORATION IN UKRAINE
}

Низка рідкіснометалевих елементів, як-от Ta, $\mathrm{Nb}, \mathrm{Li}, \mathrm{Be}, \mathrm{Sn}, \mathrm{Y}, \mathrm{TR}$, родовища яких безпосередньо пов'язані $з$ пегматитами, входять до переліку критично важливих корисних копалин США, Канади, Австралії та ЄС. Це спонукає розвивати мінерально-сировинну базу вказаних елементів, а також указує на потребу переоцінення відомих і пошуку нових родовищ рідкіснометалевих пегматитів. Передувати витратному етапу геологорозвідувальних робіт має докладний усебічний науковий аналіз наявних матеріалів про пегматити досліджуваного регіону зі створенням дієвих критеріїв та ознак прихованого зруденіння. У статті розглянуто геолого-структурні умови розвитку пегматитів та особливості гранітоїдного магматизму Східноукраїнської пегматитової області (Середнє Придніпров'я і Західне Приазов'я), які визначають спеціалізацію пегматитових асоціацій і сформованих ними пегматитових полів та поясів. Виокремлено три пегматитогенерувальні етапи розвитку пегматитової області. Показано, що з третім - граніт-зеленокам'яним етапом пов'язуються всі рідкіснометалеві пегматити області. Також проаналізовано геологічну позицію та будову двох родовищ рідкісних металів (Шевченківське - літію; Крута Балка - літію, танталу, ніобію) та враховано структурну позицію наявних рудопроявів і точок мінералізації рідкіснометалевих пегматитів. На основі геологічної інформації щодо цих родовищ і рудопроявів із залученням результатів власних досліджень і даних з відкритих джерел, сформульовано найвагоміші пошукові критерії й ознаки рідкіснометалевих пегматитів Східноукраїнської пегматитової області. Відтак надано рекомендації на проведення наукового аналізу території зі складанням загальних прогнозних карт території і детальних карт перспективних структур у масштабі 1:10 000-1:25 000; рекомендовано першочергове виконання розшуково-оцінювальних робіт у межах вузлів рідкіснометалевих пегматитів - Воскресенського, Воскресенського-2, Мокроялинського, Блакитні Скелі, Садового в Західному Приазов”ї та Комендантівського й Жовтянського в Середньому Придніпров”, а також проведення детального картування Гуляйпільського пегматитового вузла на півдні Софіївської структури.

Ключові слова: Східноукраӥнська пегматитова область, рідкіснометалеві пегматити, літій, Шевченківське родовище, пошуки пегматитів.

Nowadays, there has significantly increased the interest of industry in rare metal mineralization in pegmatites, which determines their importance as raw materials for "critical elements" $\mathrm{Ta}, \mathrm{Nb}, \mathrm{Li}, \mathrm{Be}, \mathrm{Sn}, \mathrm{Y}, \mathrm{TR}$, etc., and thus there is a need to re-evaluate the known and newly-found deposits of rare metal pegmatites. A detailed comprehensive scientific analysis of the available materials on pegmatites of the East-Ukrainian pegmatite province (Middle Dnipro and Western Azov) with the development of effective criteria and characteristics of hidden mineralization has to precede the production of costly geological exploration works. Due to the special genetic position of pegmatites in the chain of endogenous processes, their unique mineralogical-petrographic, geochemical and metallogenic properties and ability to form within well-defined structures and rock complexes, it is possible to identify very promising areas, with a detailed scientific analysis of areas. There is considered geological and structural setting and granitoid magmatism of the East-Ukrainian pegmatite region, which determine the specialization of pegmatite associations and the pegmatite fields and belts formed by them. Three pegmatitegenerating stages of development of the pegmatite region are singled out. It is shown that all rare metal pegmatites of the region are associated with the third - granite-greenstone - stage. The analysis of the geological position and structure of two deposits of rare metals (Shevchenko - lithium; Kruta Balka lithium, tantalum and niobium) was also carried out, and the structural position of the existing ore occurrences and mineralization points of rare metal pegmatites was taken into account. Based on geological data on these deposits and ore occurrences using previous developments reflected in the literature, the most important search criteria and characteristics of rare metal pegmatites of the East-Ukrainian pegmatite region are shown. Taking into account the above, there are given recommendations for scientific analysis of the territory with the compilation of general forecast maps of the territory and detailed maps of perspective structures in the scale of 1:10 000-1:25000 with analysis of geological structure and reflection of pegmatite-bearing structures, plicative failure of their strata; study of physical, physico-thermal, chemical and mineralogical properties of rocks with the development of classification of rocks according to the possibility of occurrence of pegmatite bodies in them. Primarily, it is recommended to carry out prospect evaluation survey within the clusters of rare metal pegmatites - Voskresenka, Voskresenka-2, Mokri Yaly, Golubi Skeli, Sadove in the Western Azov and Komendantivka and Zhovte in the Middle Dnipro region, as well as detailed mapping of the Hulyaipole pegmatite cluster in the south of the Sofiivka structure.

Keywords: East-Ukrainian pegmatite region, rare metal pegmatites, lithium, Shevchenko deposit, pegmatite prospecting.

Вступ. Успішний розвиток будь-якої країни світу в умовах сьогодення передбачає технологічний перехід економіки

В. В. Сукач, Л. В. Ісаков, В. П. Безвинний, В. О. Шпильчак, 2021, с. 6-15 на використання “зелених” видів енергії. Відповідно до цієі глобальної тенденції масового характеру набуває виробництво електричних автомобілів, вітрових турбін, сонячних панелей, різних типів акумуляторів та енергетичних сховищ. 
Забезпечити відповідною сировиною глобальну технологічну еволюцію покликані геологорозвідувальні роботи (ГРР) у супроводі інноваційних наукових досліджень. Вони дадуть змогу оцінити стан, визначити якість і кількість мінерально-сировинних ресурсів, потрібних для зазначених механізмів і пристроїв. Низка рідкіснометалевих елементів, як-от Та, $\mathrm{Nb}, \mathrm{Li}, \mathrm{Be}, \mathrm{Sn}, \mathrm{Y}, \mathrm{TR}$, родовища яких безпосередньо пов'язані 3 пегматитами, входять до переліку критично важливих корисних копалин США, Канади, Австралії та СС [1]. Зокрема, на території України зосереджені родовища 21 виду сировини з переліку 30 видів корисних копалин, що визначені ЄС як “критична сировина” для виробництва пристроїв і розвитку “зеленоі” енергетики, зокрема й акумуляторних батарей.

Це спонукає розвивати мінерально-сировинну базу вказаних елементів, а також указує на потребу переоцінення відомих і пошуку нових родовищ рідкіснометалевих пегматитів. У цьому плані треба звернути увагу на пегматити Українського щита (УЩ), зокрема Східноукраїнської пегматитової області в його межах, перспективної на виявлення нових родовищ літію та інших рідкісних металів поряд з уже відомим Шевченківським родовищем.

1. Постанова проблеми. В переліку стратегічної для України мінеральної сировини одна з головних позицій належить літію. Важко уявити сучасний світ без цього хімічного елемента. Окрім уже згаданого виробництва хімічних джерел струму - акумуляторів, дуже широкого діапазону за призначенням і ємністю, літій та його сполуки використовуються в електроніці, ядерній енергетиці, металургії, авіа- та ракетобудуванні, виготовленні піротехнічних, мастильних матеріалів, сплавів, застосовуються в медицині та інших галузях. Отримують метал або його сполуки в результаті гідрометалургійного перероблення літієвих руд, які в промисловій кількості зазвичай концентруються у пегматитах. Головні мінерали-концентратори літію - сподумен, петаліт, амблігоніт, літієві слюди. В останні роки стрімкими темпами зростає видобування літію з ропи солоних озер і мінералізованих підземних вод. Лідерами з видобутку літію у світі є Австралія, Чилі, Болівія.

Українські поклади літієвих руд є найбільшими в Свропі. У нашій країні є три великі родовища літієвих руд: Шевченківське (Донецька область), Полохівське і Станкуватське (Кіровоградська область). Уміст літію в рудах цілком відповідає кількості, що забезпечує економічну доцільність їхнього вилучення за допомогою сучасних технологій. Однак літієвих руд в Україні поки не добувають. Водночас за умови освоєння наявних родовищ металу та з огляду на ресурсний потенціал і виявлення нових покладів, Україна може стати одним з провідних постачальників літію на міжнародний ринок.

Треба зазначити, що приповерхневі, розкриті ерозією родовища вже виявлені й оцінені, а пошуки “сліпих" рудних покладів потребують чималих фінансових витрат, пов'язаних передусім з бурінням свердловин. У таких умовах суттєво зростає роль наукового аналізу й узагальнення наявних геолого-геофізичних матеріалів, що забезпечать пошукові роботи комплексом високоефективних критеріїв і ознак прихованого пегматитового зруденіння. Це дасть змогу вже на стадії проєктування локалізувати пошуки на ділянках, перспективних на виявлення родовищ рідкісних металів, пов'язаних з пегматитами.

2. Мета роботи. Удосконалити та систематизувати комплекс прогнозно-пошукових критеріїв та ознак рідкіснометалевих пегматитів Східноукраїнської пегматитової області.
Їхнє впровадження в практику ГРР матиме суттєвий економічний ефект унаслідок максимального зменшення пошукових потенційно рудоносних площ, а отже скорочення обсягів дуже витратних бурових робіт.

3. Стан вивченості питання. Результати різнопланових досліджень пегматитів і пов'язаних з ними родовищ рідкісних металів висвітлено у звітах про геологорозвідувальні та науково-тематичні роботи, а також у численних публікаціях [6-8, 9, 11, 15 та ін.]. Фактично за час вивчення пегматитів накопичено величезний обсяг матеріалів, які потребують ретельного аналізу, переосмислення й систематизування, щоб напрацювати нові й удосконалити вже відомі критерії та ознаки рідкіснометалевого зруденіння і вийти на якісно новий рівень прогнозно-пошукових та оцінювальних робіт. Як еталонні об'єкти для вивчення та оцінювання для нас слугували найвивченіші пегматитові об'єкти, як-от родовища Шевченківське й Крута Балка, а також рудопрояви Федорівської, Сорокинської, Комендантівської, Жовторічанської та інших структур.

Над розробленням і впровадженням у практику пошуково-оцінювальних критеріїв пегматитів працювали всі відомі дослідники пегматитів: А. Гінзбург, М. Солодов, С. Шавло, I. Недумов та ін. [6, 7, 11, 15 та ін.]. Для пегматитів східної частини УЩ комплекс оцінювальних критеріїв розробили такі дослідники, як Ю. Юрк, С. Шавло, Л. Ісаков та ін. [7, 8, 11, 13, 18 та ін.]. У працях вони наголошували, що в межах великих слабко вивчених пегматитоносних територій за умови надійних, наукового обгрунтованих параметрів зруденіння цілком можливо зосередити пошукові роботи лише на обмежених за площею, високоперспективних ділянках.

4. Рідкіснометалеві пегматити Східноукраїнської пегматитової області. Перш ніж перейти до викладення прогнозно-пошукових критеріїв пегматитового зруденіння, важливо навести опис наявних об'єктів рідкіснометалевих пегматитів Східноукраїнської області, розглянувши їхнє положення в структурі УЩ, закономірності поширення й особливості структурної локалізації зруденіння, загальні питання формування рудоносних пегматитів та інші важливі питання.

Геолого-структурні умови та гранітоїдний магматизм визначають спеціалізацію пегматитових асоціацій і сформованих ними пегматитових полів та поясів. Для мегаструктур УЩ характерна купольно-синклінорна будова. Розвиток гранітогнейсових куполів супроводжувався глибокими процесами метаморфізму, метасоматозу, ультраметаморфізму та автохтонного й алохтонного магматизму, які слугували джерелом глибинних кварц-польовошпатових пегматитів керамічної, здебільшого безрудної асоціації. 3 формуванням синклінорних, зазвичай трогових структур тісно пов'язаний процес гранітного магматизму, який супроводжувався розвитком пегматитового процесу рідкіснометалевої спеціалізаціі. 3 областями, де спостерігається проникнення в межі куполів великих гранітних батолітів, за незначного їхнього ерозійного зрізу (для України це гранітні батоліти Волинської і, певне, Інгульської мегаструктур), пов’язані асоціації камерних пегматитів.

УЩ - це пегматитова провінція [18].У його межах міститься сім мегаструктур, які тією чи іншою мірою є пегматитоносними. Із заходу на схід це такі мегаструктури: Волинська, Дністрово-Бузька, Росинсько-Тікицька, Інгульська, Середньопридніпровська, Західноприазовська і Східноприазовська. Відповідно до загальноприйнятої ієрархічної схеми пегматитів (пегматит $>$ пегматитовий вузол > пегматитове поле > пегматитовий пояс $>$ пегматитовий район > пегматитова провінція) УЩ, як загаль- 
на провінція, об’єднує сім районів: Середньопридніпровський, Західноприазовський, Східноприазовський, Інгульський, Росинсько-Тікицький, Дністерсько-Бузький і Волинський.

У структурному плані пегматити Західного Приазов'я і Середнього Придніпров'я об'єднані в Східноукраїнську пегматитову область [18] з огляду на те, що вони належать до єдиного зеленокам'яного [5, 17] етапу розвитку УЩ (рис. 1). Породно-структурні комплекси пов'язані в єдину цілісну купольно-трогову систему, головну роль у якій відіграють такі формаційні комплекси: гнейсово-кристалосланцевоамфіболітовий, граніт-плагіограніт-мігматитовий, зеленокам'яний, що відображають три основні періоди розвитку мегаструктур. Важливе значення для їі формування також має

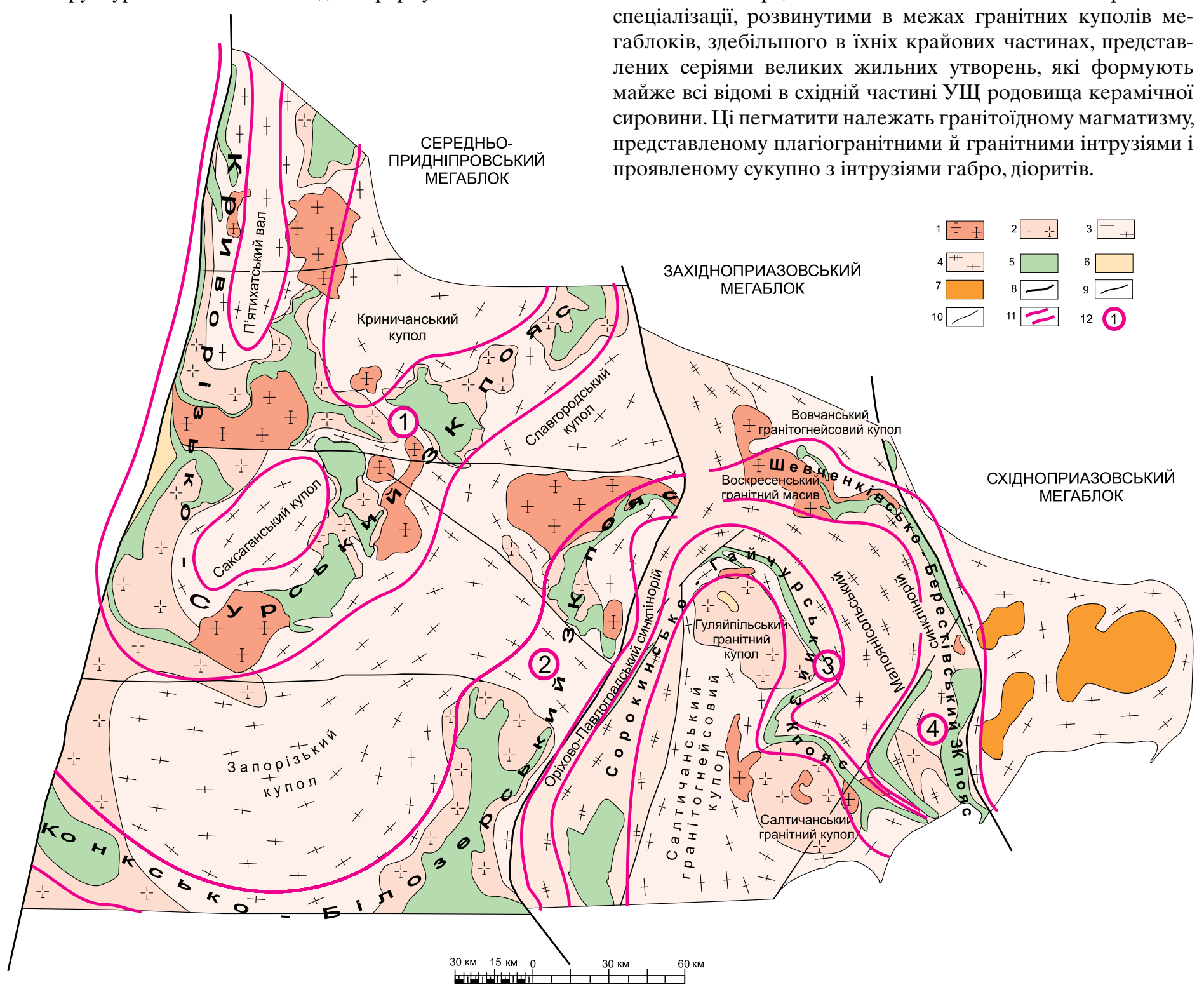

Рис. 1. Схематична геолого-структурна карта Східноукраїнської пегматитової області

1 - двопольовошпатові граніти демуринського, токівського, мокромосковського, добропільського, салтичанського, андріївського та январського комплексів; 2 - плагіограніти, тоналіти сурського, саксаганського, шевченківського комплексів та габро й діорити обіточненського комплексу; 3 - метаморфічні серії (аульська й західноприазовська) та ультраметаморфічні комплекси (славгородський, новопавлівський і дніпропетровський) купольних структур; 4 - метаморфічні товщі (вовчанська й драгунська) та ультраметаморфічні (ремівський і токмацький) комплекси синклінорних зон; 5 - метаморфізовані вулканогенно-теригенні комплекси трогових структур зеленокам'яного типу (конкська, білозерська, осипенківська серія та новогурівська, тернуватська, косівцівська товщі); 6 - теригенні комплекси прирозломних накладених структур (криворізька серія, гуляйпільська світа); 7 - габро, монцоніти, сієніти південнокальчицького й октябрського лужних інтрузивних комплексів; 8 - регіональні глибинні розломи; 9 - інші розривні порушення; 10 - геологічні границі; 11 - умовні границі пегматитових поясів: 1 - Криворізько-Сурський, 2 - Конксько-Білозерський, 3 - Сорокинсько-Гайчурський, 4 - Шевченківсько-Віслинський; 12 - номери пегматитових поясів

комплекс інтрузій габро, діоритів, плагіогранітів і двопольовопатових гранітів, укорінених під час викликаної глибинним сліджуваної площі на межі неоархею і палеопротерозою [3, 17].

Процес пегматитотворення має чітку залежність від розвитку структури мегаблоків. Перший етап пегматитотвотовщ раннього архею. Це проявляється у вигляді серії субзгідних, подекуди січних жил і шліроподібних виділень, склапегматитами [10].

Другий етап пегматитотворення представлений широкими полями кварц-польовошпатових пегматитів керамічної габлоків, здебільшого в їхніх крайових частинах, представсировини. Ці пегматити належать гранітоїдному магматизму, представленому плагіогранітними й гранітними інтрузіями і проявленому сукупно з інтрузіями габро, діоритів. 
Розвиток пегматитів третього етапу, які принесли із собою рідкіснометалеве зруденіння, пов'язаний з гранітними комплексами зеленокам'яного періоду як у Середньому Придніпров`і, так і в Західному Приазов’і. Сформований у цей період третій структурний поверх є найбільш диференційованим як за геолого-структурною будовою, так і за гранітним магматизмом, що тісно пов'язаний з розвитком і становленням зеленокам'яних структур (ЗКС). У його межах розвинені гранітні комплекси, склад яких є сталим і характерним для обох мегаблоків: демуринський, мокромосковський, токівський, добропільський, январський і салтичанський гранітні комплекси. Всі ці комплекси досить добре схарактеризовані в низці публікацій $[4,5,7,10,16-18$ та ін]. Їхній ізотопний вік за різним датуванням коливається в межах 3,1-2,1 млрд років $[3,16]$.

Вкорінення калішпатових гранітів, основних генераторів рідкіснометалевих пегматитів, тривало на завершальній стадії формування ЗКС і відбувалося поетапно з поступовим розкисненням пізніших інтрузій, або їхніх окремих фаз $[7,17,18]$. У перший період вкорінювались і формувалися гранодіорити й меланократові граніти демуринського та мокромосковського комплексів Середнього Придніпров'я, а також добропільського й январського комплексів Західного Приазов'я. Завершило процес гранітного магматизму зеленокам'яного етапу (другий період формування) вкорінення в контактові зони зеленокам'яних структур і вулканогенно-осадову товщу, яка їх виповнює, інтрузій лейкократових, двослюдяних і сублужних ортитовмісних гранітів мокромосковського й токівського комплексів (Середнє Придніпров'я) та краснокутських, андріївських і салтичанських гранітів (Західне Приазов'я). Це граніти нормального й сублужного ряду, що різко відрізняються за акцесорними рідкісними й рідкісноземельними мінералами від гранітів попереднього етапу й супроводжуються інтенсивним укоріненням пегматитів різної спеціалізації з утворенням великих пегматитових полів.

4.1. Західноприазовський пегматитоносний район. Майже за віковий період досліджень у межах Західного Приазов'я виявлено тисячі пегматитових тіл різноманітного складу, будови, геохімічної та рудної спеціалізації, з якими пов'язано три родовища рідкісних металів (Шевченківське - літію; Крута Балка - літію, танталу, ніобію; Могила Вісла - цирконію, рідкісних земель) та сотні рудопроявів і точок мінералізації рідкісних та рідкісноземельних металів, а також десятки, зокрема й детально розвіданих, родовищ керамічної сировини [7,13,15].

Рідкіснометалеві пегматитові поля локалізовані в крайових частинах Салтичанського, Гуляйпільського та Воскресенського гранітних куполів у вузьких зеленокам'яних трогових структурах, які формують два субпаралельні протяжні зеленокам'яні пояси: Шевченківсько-Берестівський і Сорокинсько-Гайчурський. Пегматити є в усіх структурах зазначених поясів, тому в їхніх межах виділено і пояси рідкіснометалевих пегматитів: Шевченківсько-Віслинський і Сорокинсько-Гайчурський (рис. 1) [7,18].
Шевченківсько-Віслинський і Сорокинсько-Гайчурський пояси мають вигнуту дугувату форму й субпаралельно простежуються в дискретно проявлених трогових ЗКС Західноприазовської мегаструктури, відповідно на 160 км і 230 км; на південно-східному іï замиканні вони об'єднуються. Ширина зон розвитку пегматитів в окремих структурах коливається від 1,5 до 5,0 км, а протяжність - від 5 до 30 км.

Шевченківсько-Віслинський пояс складений Шевченківським, Федорівським полями рідкіснометалевих пегматитів, Віслинським полем рідкісноземельних пегматитів та Вовчанським, Дібровським і Павлівським пегматитовими полями остаточно не з'ясованої спеціалізації. Ці поля розвинені в однойменних структурах, розміщених на півночі довкола та в межах Воскресенського гранітного купола з простяганням на південь уздовж Малоянісольської зони розломів.

Сорокинсько-Гайчурський пояс утворюють Сорокинське рідкіснометалеве пегматитове поле, Куйбишевське, Гайчурське рідкісноземельні пегматитові поля та Драгунське, Молочанське й Чистопільське остаточно не з'ясованої спеціалізаціі. Зазначені поля розташовані в межах однойменних структур, розвинених навколо Салтичанського гранітогнейсового купола.

3 рідкіснометалевих пегматитових полів найліпше вивчено поля Шевченківсько-Федорівської структури (рис. 2) [7].

Найпродуктивнішим у цій структурі є Шевченківський вузол (родовище) рідкіснометалевих пегматитів [7], розмі-
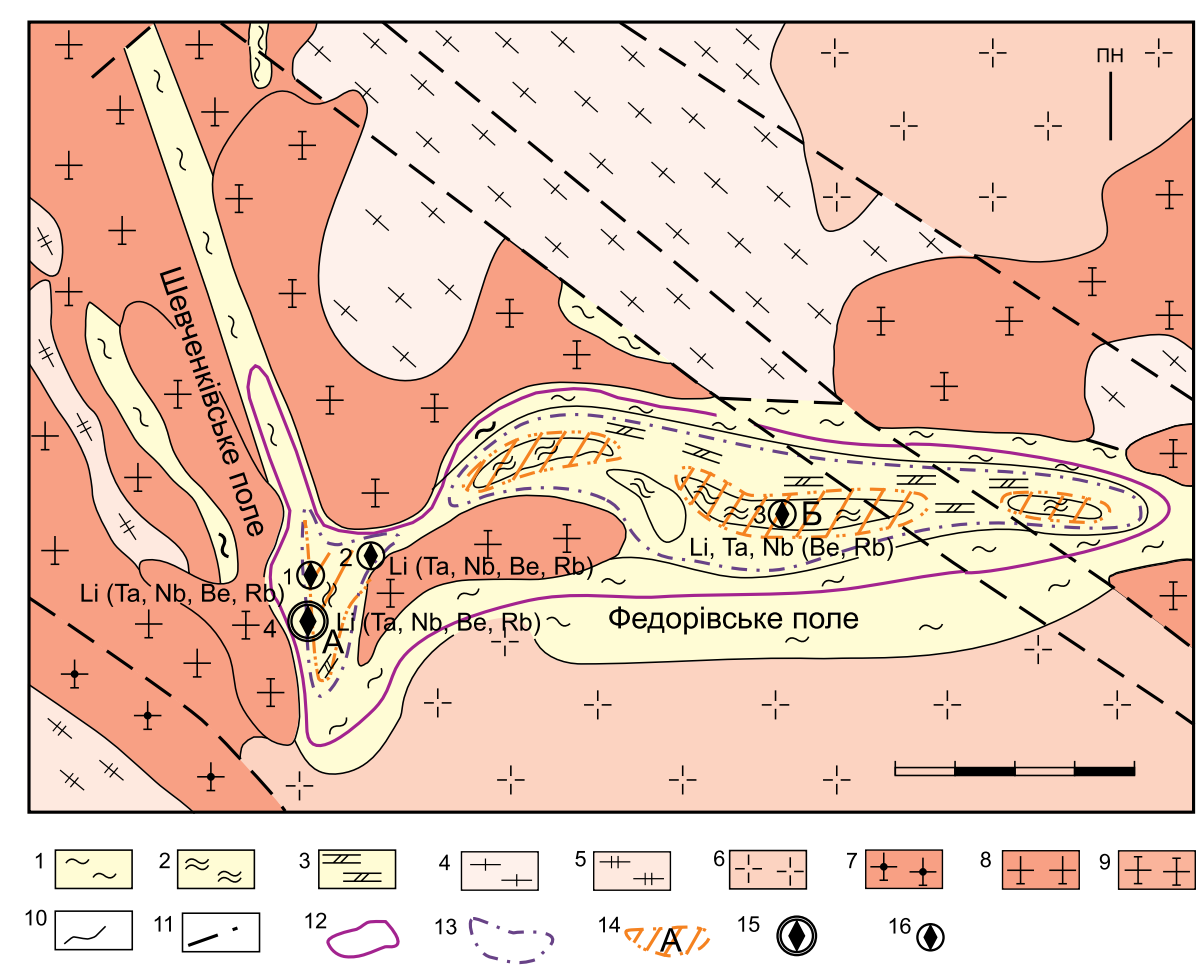

Рис. 2. Схематична карта Шевченківського та Федорівського пегматитових полів 1-3 - пегматитовмісні утворення тернуватської товщі: 1 - пачка слюдистих високоглиноземистих сланців, 2 - пачка меланократових амфіболових, амфібол-біотитових сланців, 3 - сланцево-карбонатна пачка; 4-5 - гнейсово-мігматитова товща; 6 - плагіограніти шевченківського комплексу; 7-9 - граніти январського комплексу: 7 - амфібол-біотитові з магнетитом, 8 - біотитові, 9 - мусковіт-біотитові лейкократові; 10 - межі геологічних підрозділів; 11 - розломи; 12 - межі розвитку пегматитових полів; 13 - ділянки (вузли) переважного розвитку альбітових і альбіт-мікроклінових пегматитів; 14 - ділянки (вузли) розвитку альбіт-петаліт-сподуменових та альбіт-сподуменових пегматитів: А - Шевченківський, Б - Мокроялинський; 15 - Шевченківське родовище рідкіснометалевих пегматитів; 16 - рудопрояви рідкіснометалевих пегматитів: 1 - Воскресенський, 2 - Воскресенський-2, 3 - Мокроялинський 
щений на зчленуванні Шевченківської грабен-монокліналі з Федорівською грабен-синкліналлю у кристалічних породах тернуватської товщі. У західній і південній частинах, за межами пегматитового поля, розташовані граніти Воскресенського інтрузиву, в південно-східній частині - граніти й гранодіорити архейського шевченківського комплексу (рис. 2).

Загалом у межах пегматитового вузла налічується шість пегматитових тіл єдиної жильної системи зі сталим західним падінням жил під кутами 55-88 і простяганням у південній частині за азимутом 8-26 ${ }^{\circ}$, а на півночі родовища - за азимутом 323-360․ Параметри жил змінюються в широких межах: від 144 до 1076 м за довжиною та від 2,0 до 83,8 м за потужністю. Протяжність пегматитових тіл на глибину мінлива і в окремих перетинах перевищує 500 м. Породотвірні мінерали (альбіт, мікроклін, кварц) становлять близько 80-95 \% об’єму жил. Решта 5-20 \% - це літієві мінерали, як-от сподумен, набагато рідше петаліт. Рідкіснометалеві мінерали ніобію, танталу, берилію й олова в складі жил відіграють зовсім незначну роль [7].
На північно-східному простяганні зони, що вміщує родовище, одиничними свердловинами виявлено три пегматитові жили сподумен-кварц-польовошпатового складу (рудопрояви Воскресенівський і Воскресенівський-2, які можуть являти собою окремі жили нових рідкіснометалевих пучків типу Шевченківського.

У південно-східній частині Федорівської синкліналі встановлені альбіт-мікроклінові та мікроклін-альбітові зі сподуменом пегматити, які формують Мокроялинський рудопрояв рідкісних металів. Пегматити представлені поодинокими тілами лінзо- і жилоподібної форми. Їхня потужність - від 0,2 до 13,4 м, протяжність за простяганням - 50-500 м, кут падіння - 40-60. Уміст оксидів рідкісних металів становить, \%: $\mathrm{Li}_{2} \mathrm{O}-0,038$ 1,170; $\mathrm{Rb}_{2} \mathrm{O}-0,017-0,299 ; \mathrm{Cs}_{2} \mathrm{O}-0,020-0,139 ; \mathrm{Ta}_{2} \mathrm{O}_{5}-0,0028$ 0,0104. Рудопрояв недовивчений, високоперспективний.

Сорокинсько-Гайчурський пегматитовий пояс утворюють Сорокинське рідкіснометалеве пегматитове поле, Куйбишевське, Гайчурське, Драгунське й Чистопільське поля невстановленої спеціалізації. Ці поля розташовані в межах однойменних структур, розвинутих навколо Салтичанського гранітогнейсового купола. Гіпотетично не виключено розміщення пегматитових полів у межах Молочанської структури, що майже не досліджена.

Найліпше вивчене Сорокинське пегматитове поле (рис. 3), приурочене до однойменної граніт-зеленокам'яної структури й розташоване в південній частині поясу. У межах поля визначено низку пегматитових вузлів: північно-західної частини Сорокинської ЗКС Комишуватський, Андріївський,

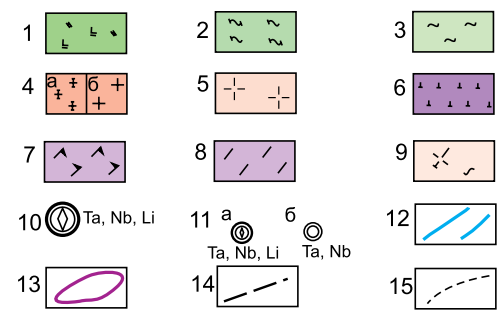

\section{Рис. 3. Схематична геологічна карта Сорокинського поля рідкіснометалевих пегматитів}

1 - метавулканіти ольжинської світи; 2 - слюдисті сланці крутобалківської світи; 3 - теригенно-хемогенні утворення садової світи; 4 - граніти: а - мусковітові й мусковіт-біотитові андріївської асоціації, б - ортитовмісні салтичанського комплексу; 5 - плагіограніти шевченківського комплексу; 6 - тіла ультрабазитів; 7 - амфібол-піроксенові гнейси та кристалосланці західноприазовської серії; 8 - біотитові гнейси драгунської товщі; 9 - плагіомігматити; 10 - родовище рідкісних металів Крута Балка; 11 - пов'язані з пегматитами: а - рудопрояви, б - аномалії рідкісних металів; 12 - контур розвитку Сорокинського пегматитового поля; 13 - вузли рідкіснометалевих пегматитів; 14 - розривні порушення; 15 - геологічні границі 
Сорокинський; південно-східної частини Сорокинської ЗКС Крута Балка, Блакитні Скелі, Садовий. Вузли Крута Балка, Блакитні Скелі та Садовий мають чітко визначену рідкіснометалеву спеціалізацію і, ймовірно, дуже тісно пов'язані між собою. Найліпше вивчений вузол Крута Балка $[7,13,15]$.

Вузол (родовище) Крута Балка $[13,15]$ представлений альбітовими й альбітовими зі сподуменом пегматитами. Розташований він у центрі Сорокинської структури в ії найширшій частині, розміщеній у зоні, де сформувалось іï фрагментарне відгалуження, що виникло у зв'язку з кільцевими розломами, які оконтурюють Салтичанський купол. 3 цього погляду структурна позиція вузла дуже подібна до позиції Шевченківського.

Пегматити вузла (мікроклінові, альбіт-мікроклінові, альбітові й альбітові зі сподуменом) $[13,15]$ утворюють серію (понад десяток) плито-, лінзоподібних, іноді грибуватих тіл, які залягають полого, мають довжину за падінням від 50 до 400 м і потужність від десятків сантиметрів до 40 м і більше в роздувах. Падіння жил південно-східне $\left(140^{\circ}\right)$ за кутів 5-25․ Найбільші жили мають східний напрям нахилу під кутом 20-80 У межах пегматитового вузла Крута Балка виокремлено чотири типи жил, які вирізняються просторовою приуроченістю, морфологією і характерними парагенезисами породотвірних і акцесорних мінералів. Це мікроклінові, альбіт-мікроклінові, альбітові й альбітові зі сподуменом пегматити.

Найяскравішим представником рідкісноземельних пегматитів є Гайчурське пегматитове поле, розміщене в межах однойменної структури [7]. Вміст рідкісноземельних мінералів у пегматитах та їхній корі вивітрювання в окремих жилах сягає: ксенотиму - 1,915 кг/т; монациту - 0,104 кг/т. Спектральним аналізом у жилах виявлено Ү (до 0,015 \%) та $\mathrm{Yb}$ (до 0,0015\%); сума рідкісноземельних елементів сягає $0,11 \%$. Уміст урану коливається від 0,0001 до 0,024 \%. У межах поля трапляються пегматити кварц-альбітового складу, незначної потужності (0,5-1,0 м) з дуже бідною тантал-ніобієвою мінералізацією, але, на наш погляд, основних тіл рідкіснометалевих пегматитів не виявлено.

4.2 Середньопридніпровський пегматитовий район слабко вивчений на пегматити. За загальними геологічними даними й аналогією з іншими кристалічними масивами світу та за наявними фактичними даними в межах Середнього Придніпров'я умовно виокремлено Криворізько-Сурський і Конксько-Білозерський пегматитові пояси, у які об'єднані всі зеленокам'яні структури, включно і з Криворізько-Кременчуцькою зоною (рис. 1) [18].

Серед рудних пегматитів району слід зазначити пегматити Комендантівської та Жовтоводської ЗКС Криворізько-Кременчуцької зони й поодинокі прояви рудних пегматитів у межах Конкської, Верхівцівської та Софіївської ЗКС. Нині встановлено Жовтоводське та Комендантівське поля рідкіснометалевих пегматитів (рис. 4).

Жовтоводське поле $[9,14]$ розташоване в межах Жовторічанської ЗКС. Пегматити залягають субзгідно зі сланцюватістю вмісних метаморфічних порід. Потужність жил змінюється в межах 0,5-10 м, окремі жили в роздувах досягають 15 м. Склад жил кварц-мікрокліновий, кварц-альбітовий, кварц-альбіт-мікрокліновий, сподумен-кварц-мікроклін-альбітовий $з$ полуцитом, полуцит-кварц-сподумен-альбітовий, кварц-полуцит-мікрокліновий. Зазначимо, що ці пегматити - єдині полуцитоносні в межах УЩ [14]. На жаль, цілеспрямованих досліджень пегматитового поля не проводили. Даних про звичайне опробування немає. Проте, зважаючи на спорадично отримані фактичні дані й наведений вище аналіз, у межах поля треба сподіватися на великі диференційовані тіла пегматитів альбіт-мікроклінового типу, які можуть містити промислові запаси літію, танталу й цезію.

Комендантівське пегматитове поле приурочене до однойменної ЗКС яка, за аналогією з Жовторічанською, оперяє Криворізько-Кременчуцьку зону. За мінеральним складом визначено такі типи пегматитів: мікроклін-олігоклазові, альбітові, альбітові зі сподуменом, альбіт-сподуменові $[2,9,18]$.

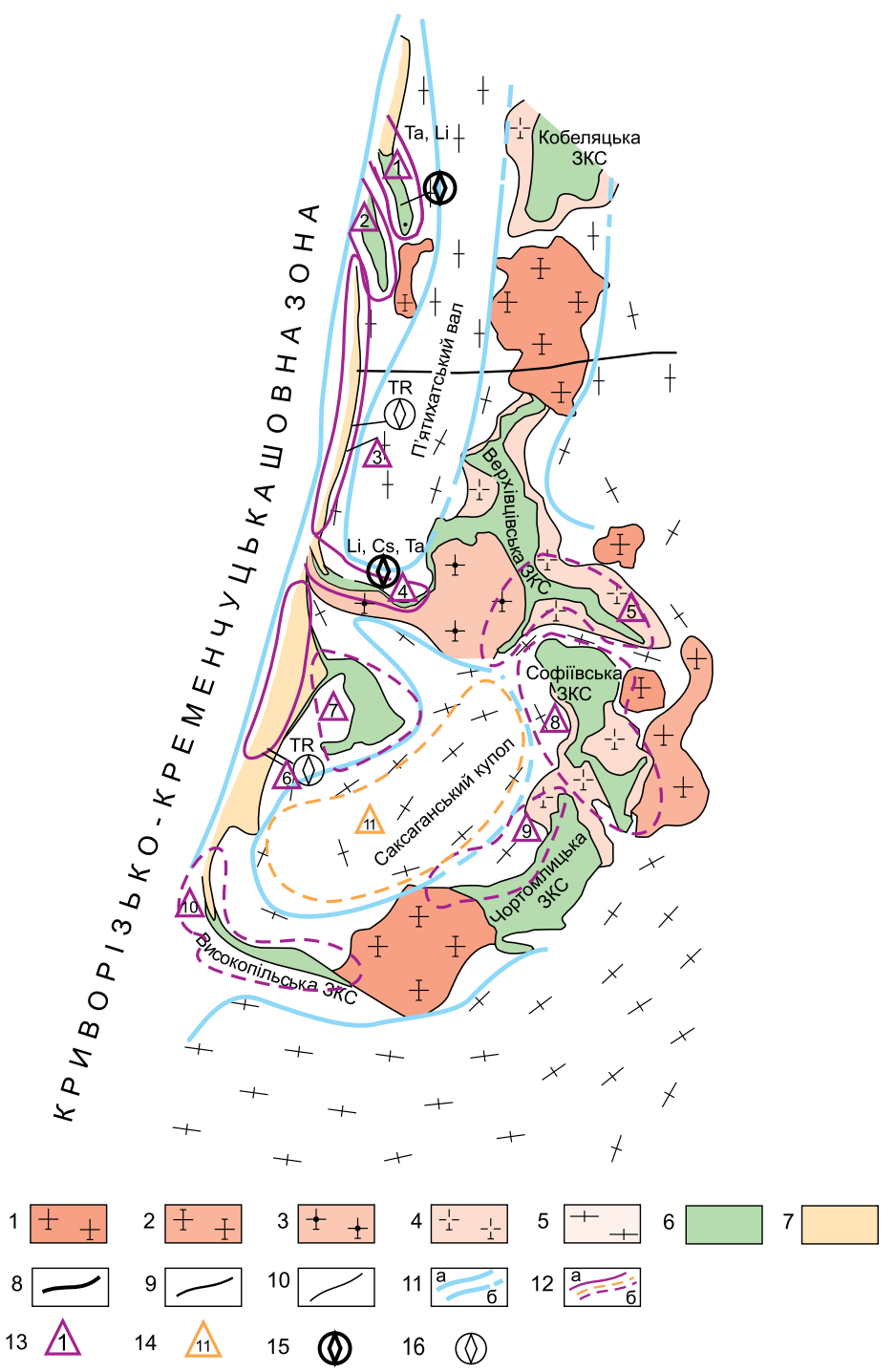

Рис. 4. Схематична геологічна карта пегматитових полів західної частини Середньопидніпровського пегматитового району Гранітні інтрузивні комплекси: 1 - токівський; 2 - мокромосковський; 3 - демуринський; 4 - сурський плагіогранітний інтрузивний комплекс; 5 - дніпропетровський ультраметаморфічний плагіограніт-мігматитовий комплекс та амфіболіто-гнейсовий породний комплекс аульської серіі; 6 - вулканогенно-теригенні метаморфізовані утворення зеленокам'яних структур; 7 - вулканогенно-теригенні утворення Криворізької структури. Розломи: 8 - глибинні, 9 - головні. 10 - геологічні границі. Умовні границі Комендантівсько-Жовтоводсько-Мокромосковського пегматитового поясу: 11а - вірогідні, $11 б$ - імовірні. Границі пегматитових полів: 12а - вірогідні, 126 - імовірні. 13 - поля рідкіснометалевих і рідкісноземельних пегматитів: 1 - Комендантівське, 2 - Паньківське, 3 - Миколаївське, 4 - Жовтоводське, 5 - Південноверхівцівське, 6 - Східноаннівське, 7 - Тернівське, 8 - Софіївське, 9 - Західночортомлицьке, 10 - Високопільське. 14 - Базавлуцьке (11) поле керамічних пегматитів; 15 - рудопрояви рідкісних металів, пов'язаних з пегматитами; 16 - рудопрояви рідкісноземельних металів, пов'язаних з пегматитами 
Загалом у межах вузла відшукали понад 30 жил, що містять аномальну кількість рідкісних металів, серед них $\mathrm{Ta}_{2} \mathrm{O}_{5}-$ $0,08 \% ; \mathrm{Nb}_{2} \mathrm{O}_{5}-0,14 \% ; \mathrm{Li}_{2} \mathrm{O}-1,6 ; \mathrm{Rb}_{2} \mathrm{O}-0,07$ \%. Зважаючи на геолого-структурні особливості цього рудопрояву й дані аналітичних досліджень, можна, за аналогією до відомих родовищ, сподіватися на виявлення родовища рідкісних металів.

Умовно виокремлені пегматитові поля Паньківське, Високопільське й Тернівське, що належать до однойменних зеленокам'яних структур, які оперяють Криворізько-Кременчуцьку зону, нині не досліджені. Проте через геолого-структурну позицію, дуже близьку до відомих полів Комендантівського й Жовтоводського, їх можна розглядати як прогнозовані поля рідкіснометалевої спеціалізації.

На сході Середнього Придніпров'я розвинуте Мокромосковське пегматитове поле (рис. 4) $[9,15,18]$, яке охоплює всю західну частину Конкської структури та контактову зону Мокромосковського масиву. За мінеральним складом серед пегматитів виокремлюються біотит-олігоклазові, біотит-мікроклін-олігоклазові, мусковіт-олігоклаз-мікроклінові, мусковіт-мікроклін-олігоклаз-альбітові та мусковіт-кварц-альбіт-мікроклінові різновиди. Підвищений уміст рідкісних металів виявлено в окремому прожилку пегматиту: Ta $(0,005 \%)$ i Nb $(0,009 \%)$, Be $(0,0001 \%)$, La $(0,002 \%)$, $\mathrm{W}(0,0005 \%), \mathrm{Bi}(0,0001 \%)$. Високий уміст рідкісних металів ( $\mathrm{Li}, \mathrm{Rb}, \mathrm{Cs}, \mathrm{Be}, \mathrm{Nb}, \mathrm{W}, \mathrm{Sn}, \mathrm{Bi}$ ) виявлено також у зоні метасоматичних змін і грейзенізації в породах Кирпотинської синкліналі та в приконтактовій частині Мокромосковського гранітоїдного масиву.

Особливої уваги потребують південна частина Верхівцівської й Софіївська структури та зони їхнього облямування. Пегматити в межах цих структур майже не вивчені, однак на підставі досить фрагментарних даних у їхніх межах свого часу було виокремлено такі пегматитові поля: Грушево-Рудицинське, Орільське, Карнаухівське та Гуляйпільське [9]. У мінералогічних пробах 3 кори звітрювання вилучено танталіт-колумбіт, ільменіт, монацит, циркон, апатит, пірит, галеніт, торит. Уміст оксидів рідкісних металів становить: $-0,002-0,009 \%-\mathrm{Ta}_{2} \mathrm{O}_{5} ;-0,003-0,013 \%-\mathrm{Nb}_{2} \mathrm{O}_{5}$, а їхнє співвідношення $\left(\mathrm{Ta}_{2} \mathrm{O}_{5}: \mathrm{Nb}_{2} \mathrm{O}_{5}\right)$ 0,5-3,0 вказує на високу перспективність пегматитів на танталове зруденіння. Поля пегматитів Софіївської структури також не вивчено, але ж ця структура, як найбільш еродована, $є$, очевидно, найперспективнішою на рідкіснометалеві пегматити серед ЗК структур Середнього Придніпров'я.

5. Пошукові критерії та ознаки рідкіснометалевих пегматитів Східноукраїнської області. Нижче сформульовано визначальні критерії прогнозування та оцінення територій окремих пегматитоносних зон і пегматитів на рідкіснометалеве зруденіння, пов'язане з пегматитами.

Віковий критерій. Передусім треба зазначити, що геологічні спостереження й визначення радіологічного віку пегматитів указують на те, що пегматити утворюються в усі геологічні епохи. Але водночас підраховано, що з усіх відомих нині пегматитів приблизно 80 \% становлять докембрійські прояви, тобто пегматити для докембрійських утворень не $є$ унікальним, а радше звичайним явищем. На родовища пегматитів архею і протерозою припадає понад 70 \% усіх пегматитових запасів Li, Cs, Ta, Be, Sn i більшість родовищ керамічної сировини. Виявлені вони в межах пегматитових поясів Канадського, Австралійського, Балтійського та інших щитів. Отже, мають бути наявними і в межах подібного УЩ, що також має вік архею і раннього протерозою. Розміщені в межах трогових структур Західного Приазов'я та Середнього Придніпров'я рідкіснометалеві пегматити відповідають головним умовам розвитку пегматитів зазначених давніх платформ, але вони значно (в десятки разів) поступаються їм за запасами. На нашу думку, нові дослідження пегматитів області можуть різко скоротити це відставання.

Геолого-структурний критерій. Основна маса пегматитів рідкіснометалевої спеціалізації локалізується в межах ЗКС в облямуванні гранітних куполів і масивів, формуючи протяжні пояси. Останні зазвичай простягаються на сотні кілометрів, а приурочені до них пегматитові поля здебільшого лінійно витягнені на відстань до 20 й більше кілометрів та складені серіями у вигляді пучків зближених плитоподібних або еліпсоїдних округлих тіл. Класичним прикладом цього $€$ Шевченківсько-Берестівський і Сорокинсько-Гайчурський пояси Західного Приазов’я.

Геолого-генетичний критерій. Більшість дослідників пегматитів $[6,7,18]$ зазначає, що для докембрійських пегматитів рідкіснометалевої асоціації характерний суттєвий зв'язок з гранітними масивами, а Л. В. Ісаков [7] вважає такий зв'язок обов'язковим. Зазвичай це диференційовані масиви 3 фазами чи субфазами невеликих тріщинних, витягнених уздовж розломів нормальних і сублужних мусковітовмісних і лейкократових гранітів.

Прикладом може слугувати Воскресенський багатофазний інтрузив [7]. Калієві амфібол-біотитові граніти цього інтрузиву належать до групи гранодіоритів, біотитові - до нормальних гранітів, мусковіт-біотитові - до групи лейкогранітів. Усі вони - утворення нормальної вапнисто-лужної серії. Від першої до наступної фази в породах масиву збільшується вміст $\mathrm{SiO}_{2}, \mathrm{~K}_{2} \mathrm{O}$, $\mathrm{Na}_{2} \mathrm{O}$ і зменшується - $\mathrm{CaO}, \mathrm{MgO}, \mathrm{FeO}, \mathrm{TiO}_{2}$. Від першої до наступних фаз гранітів підвищується вміст рідкісних металів. Пегматити полів просторово пов'язані із зонами розвитку тріщинних мусковіт-біотитових і лейкократових краснокуцьких гранітів найпізнішої фази становлення інтрузиву.

Чинник глибинності формування. Важлива глибинність формування пегматитів. Пегматитовий розчин-розплав саме на глибині нижче від 1,5 км кристалізується без втрати флюїдної частини [6]. А. Гінзбург з колегами наводять таку емпіричну залежність розвитку рідкіснометалевих пегматитів зі збільшенням ступеня метаморфізму. 3 кордієрит-амфіболовою фацією (примежова 3 породами зеленосланцевої фаціi) асоціюють альбітові й мікроклін-альбітові танталоносні пегматити; до зони розвитку кордієриту (кордієрит-ставроліт-гранат-андалузит-слюдисті, іноді силіманітовмісні сланці) приурочені поля мікроклін-альбітових пегматитів зі сподуменом та альбіт-сподуменові пегматити. 3 більш високотемпературними стадіями метаморфізму пов'язані альбіт-мікроклінові різновиди, мікроклінові пегматити з берилом, каситеритом. Наведена закономірність дає змогу різко обмежити площі розшуків рідкіснометалевих пегматитів, оскільки описаним умовам відповідають тільки утворення, розвинені в трогових структурах $3 \mathrm{KC}$.

Структурно-літологічний критерій. На локалізацію, потужність, форму, склад, а також рудну спеціалізацію певним чином впливають мікроструктурні особливості вмісного літологічного комплексу та співвідношення у їхній будові породних різновидів, фізичні та хімічні властивості, мінеральний склад тощо. Передусім це розвиток дрібних плікативних складок і різкого підвертання самих структур чи їхніх складників, що сприяють утворенню закритих тріщин-пасток у жорстких породах, розміщених серед пластичних порід. 
Вплив уміщувального породного комплексу. Для локалізації великих тіл і пучків пегматитових тіл потрібні, по-перше, жорсткі породи, здатні до розтріскування з утворенням значних порожнинних тріщин, а по-друге - літологічна диференціація вмісної товщі з чергуванням м'яких (наприклад, слюдисті сланці) і твердих (роговики, основні та ультраосновні утворення) порід, що сприяло б у разі стресових навантажень формуванню в останніх порожнинних тріщин. У науковій літературі подібних умов наведено безліч. Наприклад, за працею [6], пегматити Кольського півострова локалізовані майже повністю в лінзоподібних тілах амфіболітів, які становлять усього 3 \% від загальної маси сланців пегматитоконтролювальних зон. Для східної частини УЩ виявлено такі характерні умови. Рідкіснометалеві пегматити Шевченківського вузла локалізовані в межах масивних ороговикованих амфіболових сланців і скарнованих кальцифірів, облямованих пластичними слюдистими сланцями в зоні різкого горизонтального підвертання структури. Рідкіснометалеві пегматити пучка Крута Балка локалізовані в межах масиву ультраосновних порід, облямованого тими ж слюдистими сланцями в зоні відокремлення вузької грабеноподібної гілки від головної пегматитовмісної структури.

Хімічний і мінеральний склад порід, які вміщують пегматити, так само може суттєво впливати на склад пегматитових жил. Зазначимо, що А. Гінзбург з колегами [6] розробили класифікацію порід за ступенем сорбції (поглинання) лужних і рідкісних металів. До інертного класу зачислено кварцити й кристалічні вапняки; базити й ультрабазити визнано такими, що поглинають слабко; різні слюдисті сланці поглинають активно. Можна припустити, що в інертних (неактивних) породах пегматити зберігають флюїдну фазу майже в повному обсязі, тому вони збагачені рідкісними металами та їніми мінералами; у породах активних і здатних до сорбції (слюдовмісних) пегматити разом 3 флюїдною фазою розсіюють у вмісні породи рідкісні метали у виді ореолів. Очевидно, саме тому в межах північної частини Шевченківської структури у слюдистих породах наявні великі ореоли літію й немає пегматитів з рідкіснометалевими мінералами. Подібне спостерігається на родовищі Крута Балка в місцях переходу пегматитів з ультраосновних порід у слюдисті сланці [13].

Зональність пегматитових об'єктів. Переважна більшість пегматитових полів і вузлів мають зональну будову, а тому з'ясування типу пегматитів сприяє ефективним розшукам пегматитів відповідної спеціалізації за простяганням, поперек простягання або за потужністю залежно від типу їхньої зональності. Для виявлення подібних закономірностей потрібне детальне вивчення складу пегматитів, їхньоі внутрішньої будови, форми залягання, зв'язку з материнськими гранітами тощо. Поля рідкіснометалевих пегматитів давніх платформ зазвичай складені широко розвиненими в їхніх межах безрудними пегматитами мікроклін-олігоклазового складу із шерлом і гранатом та одним або щонайбільше двома-трьома вузлами різних чи одного типу пегматитів рідкіснометалевої спеціалізації. 3 наближенням до рідкіснометалевих пегматитових пучків спостерігається розвиток у зазначених пегматитах апографічних структур і суттєве збагачення їх рідкісними металами (аж до появи власних мінералів). Пегматитові пучки (вузли) $[6,7,11]$ мають таку будову: $з$ віддаленням від материнського гранітного масиву мікроклінові й мікроклін-олігоклазові пегматити змінюються мікроклін-альбітовими й альбітовими, найбільше віддалені альбіт-сподуменові різновиди. Можливе "випадіння" iз зазначеного ряду окремих типів пегматитів і наявність у пучку здебільшого двох типів пегматитів, що притаманне й Шевченківському пучку [7]. В його межах виявлено тільки альбітові й альбіт-сподуменові пегматити. Шевченківський тип пучка - це серія стрімкоспадних жил лінзо-плитоподібної форми драбинчастого закладення в зонах тектонічних переміщень і різких горизонтальних підвертань плікативних структур. Повніший пучок утворюють пегматити родовища Крута Балка. В його межах виявлено мікроклінові, альбітові й альбітові зі сподуменом пегматити. Крутобалківський тип пучка - це серії пегматитових тіл, які полого залягають у тріщинах відриву в масивах основних та ультраосновних порід.

6. Специфіка досліджень пегматитів. Спеціалізацію пегматитових тіл можна виявити під час безпосереднього вивчення їхньої внутрішньої будови, мінерального складу структурних зон, комплексів; через вузькоспрямоване дослідження мінералів як самих пегматитів, так і зон екзоконтактів; з'ясування геохімічних особливостей пегматитових тіл та ореолових зон навколо них. Це такі ознаки, як мінералого-геохімічні, структурно-текстурні, петрохімічні, термобарогеохімічні, термолюмінесцентні. Під час мінералогічних досліджень треба визначити загальний мінеральний склад порід, мінеральні асоціації (наприклад, для пегматитів Шевченківського родовища їх виявлено 10) та структурну мінералогічну зональність. На цій підставі з'ясовують тип пегматиту і його практичну цінність.

В. Павлишин з колегами [12] в ІГМР НАНУ розробили групу специфічних оцінювальних методів дослідження мінералів: кварцометричний, слюдометричний, польовошпатометричний тощо, за допомогою яких можна визначати перспективність пегматитів, що містять досліджуваний мінерал. Мінерали аналізують способом радіоспектроскопічного, люмінесцентного, термобарогеохімічного та інших аналізів (валове й індивідуальне вивчення). Ці методи в разі детального їх напрацювання стосовно мінералів пегматитів можуть виявитися інформативнішими, ніж візуальні спостереження.

Висновки та рекомендації. Геологознімальні та цілеспрямовані геологорозвідувальні роботи на пегматити в межах Східноукраїнської пегматитової області виконані спорадично, без огляду на специфіку картування, опошукування та оцінення пегматитоносних територій, і здебільшого не дають упевненості в наявності чи відсутності родовищ рідкіснометалевих пегматитів навіть на територіях з досить детальним виконанням геологорозвідувальних робіт. Так у Західному Приазов ї в межах Федорівської структури, покритої глибинним картуванням масштабу 1:50000 і детальними пошуковими роботами, залишилися майже не дослідженими виявлені рідкіснометалеві пегматити з танталіт-колумбітом, сподуменом, берилом, розміщені у південно-східній ділянці структури; не досліджена північна частина зони зчленування із Шевченківською структурою, де наявні одиничні перетини рідкіснометалевих пегматитів. У межах Сорокинської структури більшість зі знайдених проявів рідкіснометалевих пегматитів не оцінена, зокрема, такі перспективні рудопрояви, як Блакитні Скелі й Садовий. Відоме родовище Крута Балка цієї структури також не повною мірою вивчене й може вміщувати набагато перспективніші на промислове зруденіння типи пегматитів - альбіт-мікроклінові та альбіт-сподуменові. У межах Середнього Придніпров'я, за винятком Комендантівської структури, цілеспрямованих пошукових робіт на пегматити рідкіснометалевої спеціалізації не проводили. Але ж і пегматити Комендантівського пегматитового поля 
було хибно пов'язано із січною до однойменної пегматитовмісної ЗКС (якої на той час ще не встановили) післярудною розломною зоною, що не дало змоги простежити їх за простяганням і виокремити хоча б рудопрояв рідкіснометалевих пегматитів. Рідкіснометалевих пегматитів Жовтянського пегматитового поля не досліджували взагалі, і це при тому, що в межах пегматитовмісної структури тривалий час проводили підземні експлуатаційні роботи на уран. Але згідно з фрагментарними даними й окремими публікаціями там наявні танталові, літієві та цезієві пегматити. Міжвідомчі перепони явно призвели до втрати родовищ цінних металів у цій структурі. Через брак достатнього наукового обгрунтування майже не вивчено на рідкіснометалеві пегматити такі структури, як Гайчурська, Куйбишевська, Павлівська, Драгунська, Вовчанська й Дібровська в Західному Приазов”ї, а також Конкська, Софіївська, Верхівцівська й низка ЗКС уздовж Криворізької структури в Середньому Придніпров”ї. Не проведено робіт з визначення ерозійного зрізу зеленокам'яних структур, а дані таких досліджень спрямували б роботи на більш перспективні ділянки структур.

Аналізування території досліджень на підставі окреслених вище критеріїв і ознак рідкіснометалевого зруденіння, пов'язаного з пегматитами, дало нам змогу надати такі пропозиції стосовно проведення в межах східної частини УЩ геологорозвідувальних робіт на рідкіснометалеві й керамічні пегматити:

- виконати попередній науковий аналіз наявного фактичного матеріалу щодо пегматитовмісних структур і гранітоїдів, розвинених в облямуванні та в межах цих структур, а також власне пегматитів; скласти загальні прогнозні карти Середньопридніпровської і Західноприазовської структур масштабу 1:500 000 та детальні прогнозні карти перспективних структур у масштабі 1:10000-1:25000;

- виконати геолого-прогнозне картування масштабу 1:25 000 пегматитовмісних структур. Зокрема, у Західному Приазов і: І етап - картування Шевченківської, Федорівської, Вовчанської, Дібровської структур у північній частині регіону та Сорокинської в південній його частині; II етап - картування Гайчурської, Куйбишевської та Драгунської структур. У Середньому Придніпров ї: картування Комендантівської, Жовтоводської, Софіївської і Конкської структур;

- виконати розшуково-оцінювальні роботи в межах виявлених вузлів рідкіснометалевих пегматитів - Воскресенського, Воскресенського-2, Мокроялинського, Блакитні Скелі й Садового в Західному Приазов”ї та Комендантівського і Жовтянського в Середньому Придніпров’і, провести детальне картування Гуляйпільського пегматитового вузла на півдні Софіївської структури.

У результаті проведення зазначених ГРР буде оцінено та з'ясовано промислові перспективи вже відомих рудопроявів рідкіснометалевих пегматитів, а також виявлено нові, пов'язані $з$ пегматитами, рудопрояви та родовища рідкісних металів.

\section{ЛІТЕРАТУРА}

1. Баряиька Н. В. Поняття критичної сировини - інструмент стимулювання розвитку надрокористування в Україні//Мінеральні ресурси України. - 2020. - № 2. - С. 13-18.

2. Берзенин Б. 3., Бобров А. Б., Кичурчак В. М. Физико-химические условия образования редкометалльных пегматитов Среднего Приднепровья//Геохимия и рудообразование. - 1981. - Вып. 9. - C. 63-66.

3. Бибикова Е. В., Лобач-Жученко С. Б., Артеменко Г. В. и др. Позднеархейские магматические комплексы Приазовского терейна
Украинского щита: геологическое положение, изотопный возраст, источники вещества//Петрология. - 2008. - Т. 16. - № 3. - С. 27-247.

4. Бобров О. Б., Ісаков Л. В., Сукач В. В. та ін. Комендантівська структура - нова зеленокам'яна структура Середньопридніпровського мегаблока Українського щита//Збірник наукових праць УкрДГРІ. - 2007. - № 4. - С. 10-25.

5. Бобров О. Б., Сіворонов А. О., Малюк Б. І., Лисенко О. А. Тектонічна будова зеленокам'яних структур Українського щита// Зб. наук. праць УкрДГРІ. - 2002. - № 1-2. - С. 46-67.

6. Гинзбург А. И., Тимофеев И. Н., Фельдман Л. Г. Основы геологии гранитных пегматитов. - Москва: Недра, 1979. - 296 с.

7. Ісаков Л. В. Поля гранітних пегматитів Західного Приазов'я. К.: УкрДГРІ, 2007. - 134 с.

8. Ісаков Л. В. Стислий огляд прогнозно-пошукових критеріїв та ознак рідкіснометалевого зруденіння, пов'язаного з пегматитами Західного Приазов'я//Збірник наукових праць УкрДГРІ. - 2006. - № 2. - С. $8-15$.

9. Ісаков Л. В., Бобров О. Б. Пегматитові поля Середньопридніпровського пегматитового району та основні геологічні чинники їх формування//Зб. наук. праць УкрДГРІ. - 2007. - № 3. - С. 35-45.

10. Ісаков Л. В., Сукач В. В., Курочка О. О. та ін. Нові дані про речовинний склад та формаційна належність плагіогранітоїдів Саксаганського купола (Середньопридніпровський мегаблок Українського щита)//Зб. наук. праць УкрДГРІ. - 2007. - № 2. - С. 90-97.

11. Никаноров А. С. Гранитные пегматиты. - М.: Недра, 1979. - 168 с.

12. Павлишин В. И., Багмут Н. Н., Возняк Д. К. и др. Минералогические критерии рудоносности гранитов и пегматитов (на примере месторождений и рудопроявлений Украины)//Минерал. журн - 1991. - № 13. - C. 3-24.

13. Розанов К. И., Лавриненко Л. Ф. Редкометалльные пегматиты Украины. - М.: Наука, 1979. - 139 с.

14. Савин Б. М. Локализация и минералогическая зональность гранитных пегматитов Желтореченского района/Б. М. Савин, В. Д. Евтехов//Минерал. журн. - 1993. - Т. 15. - № 3. - С. 85-91.

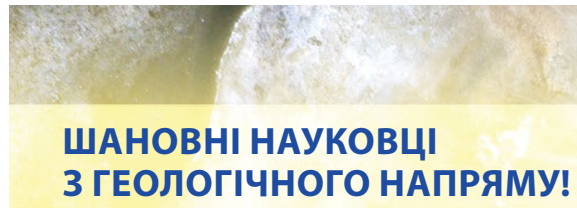

\section{Запрошуємо вас до співпраці!}

Пропонуємо сторінки нашого видання для висвітлення ваших наукових досліджень.

У 2020 році журнал укотре підтвердив свій високий науковий рівень, пройшовши перереєстрацію наукових фахових видань України на підставі рішення атестаційної комісії МОH

Йому надано категорію " " з геологічної (17.03.2020 р.) і технічної (17.03.2020 р.) галузей науки за спеціальностями:

103 - науки про Землю,

184 - гірництво,

185 - нафтогазова інженерія та технологіiі.

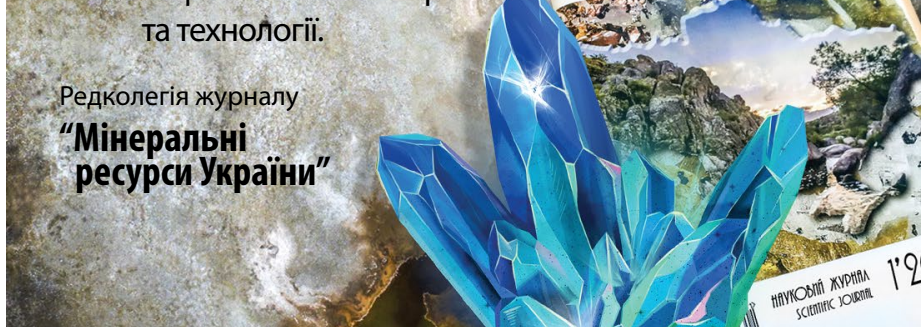


15. Шавло С. Г., Кирикилица С. И., Князев Г. И. Гранитные пегматиты Украины. - К.: Наукова думка, 1984. - 263 с.

16. Щербак Н. П., Артеменко И. М., Лесная И. М., Пономаренко A. Н. Геохронология раннего докембрия Украинского щита. - К.: Наукова думка, 2005. - 243 c.

17. Isakov Leonid V., Maria L. Isakova. Location pattern and genetic classification of granite pegmatites of the Ukrainian Shield//Journ. Geol. Geograph. Geoecology. - 2019. - № 28 (4). - P. 631-639.

18. Isakov Leonid $V$. The origin of megastruktures of the Ukrainian Shield in view of the magmatic plume concept//Dniprop. Univer. Bulletin. Geology, geography. - 2017. - № 25 (2). - C. 58-72.

\section{REFERENCES}

1. Bariatska $N$. $V$. The concept of critical raw material as a tool to stimulate the development of subsoil use in Ukraine//Mineralni resursy Ukrainy. - 2020. - № 2. - P. 13-18. (In Ukrainian).

2. Berzenin B. Z., Bobrov A. B., Kichurchak V. M. Physical and chemical formations of rare-metal pegmatites of the Middle Dnieper//Geohimiya i rudoobrazovanie. - 1981. - Iss. 9. - P. 63-66. (In Russian).

3. Bibikova E. V., Lobach-Zhuchenko S. B., Artemenko G. V. et al. Late Archean igneous complexes of the Azov Terrain of the Ukrainian Shield: geological location, isotopic age, sources of matter//Petrologiya. 2008. - Vol. 16. - № 3. - P. 227-247. (In Russian).

4. Bobrov O. B., Isakov L. V., Sukach V. V. et al. Komendantivska structure is a new greenstone structure of the Serednoprydniprovskyi megablock of the Ukrainian shield//Zbirnyk naukovykh prats UkrDHRI. - 2007. - № 4. - P. 10-25. (In Ukrainian).

5. Bobrov O. B., Sivoronov A. O., Maliuk B. I., Lysenko O. A. Tectonic structure of greenstone structures of the Ukrainian Shield// Zbirnyk naukovykh prats UkrDHRI. - 2002. - № 1-2. - P. 46-67 (In Ukrainian).

6. Ginzburg A. I., Timofeev I. N., Feldman L. G. Fundamentals of granite pegmatite geology. - Moskva: Nedra, 1979. - 296 p. (In Russian).

7. Isakov L. V. Fields of granite pegmatites of the Western Azov. Kyiv: UkrDHRI, 2007. - 134 p. (In Ukrainian).

8. Isakov $L$. V. Summary of the forecast-and-search criteria and signs of rare metal mineralization associated with pegmatites of the Western Pryazovia//Zbirnyk naukovykh prats UkrDHRI. - 2006. - № 2. - P. 8-15 (In Ukrainian).

9. Isakov L. V., Bobrov O. B. Pegmatite fields of the Middle Pridneprovsky pegmatite region and the main geological factors of their formation//Zbirnyk naukovykh prats UkrDHRI. - 2007. - № 3. - P. 35-45. (In Ukrainian).

10. Isakov L. V., Sukach V. V., Kurochka O. O. et al. New data on the mineral composition and formation occurrence of plagiogranitoids in Saksagan dome (Middle Prydniproviamegablock of the Ukrainian Shield)//Zbirnyk naukovykh prats UkrDHRI. - 2007. - № 2. - P. 90-97. (In Ukrainian).

11. Nikanorov A. S. Granite pegmatites. - Moskva: Nedra, 1979. 168 p. (In Russian).

12. Pavlishin V. I., Bagmut N. N., Voznyak D. K. el al. Mineralogical criteria for ore content of granites and pegmatites (on the example of deposits and ore occurrences in Ukraine) //Mineral. zhurn. - 1991. - № 13. P. 3-24. (In Russian).

13. Rozanov K. I., Lavrinenko L. F. Rare metal pegmatites of Ukraine. - Moskva, 1979. - 139 p. (In Russian).

14. Savin B. M., Evtehov V. D. Localization and mineralogical zonation of granitic pegmatites of the Zheltorechenske district//Mineral zhurnal. - 1993. - Vol. 15. - № 3. - P. 85-91. (In Russian).

15. Shavlo S. G., Kirikilica S. I., Knyazev G. I. Granite pegmatites of Ukraine. - Kyiv: Naukova dumka, 1984. - 263 p. (In Russian).

16. Shherbak N. P., Artemenko I. M., Lesnaya I. M., Ponomarenko A. N. Geotechnology of the early Pre-Cambrian Ukrainian Shield. - Kyiv: Naukova dumka, 2005. - 243 p. (In Russian).

17. Isakov Leonid V., Maria L. Isakova. Location pattern and genetic classification of granite pegmatites of the Ukrainian Shield//Journ. Geol Geograph. Geoecology. - 2019. - № 28 (4). - P. 631-639.

18. Isakov Leonid $V$. The origin of megastruktures of the Ukrainian Shield in view of the magmatic plume concept//Dniprop. Univer. Bulletin. Geology, geography. - 2017. - № 25 (2). - C. 58-72.

Рукопи с о тримано 28.10.2021.
ДО ВІДОМА ABTOPIB MHIHPPIABHII PECYPCH
YKPAIIHIII

\section{ДЛЯ ДАЛЬШОГО ПІДВИЩЕННЯ НАУКОВОГО РЕЙТИНГУ ЖУРНАЛУ ТА ЙОГО ДОПИСУВАЧІВ ВАРТО ЗВЕРНУТИ УВАГУ НА ТАКЕ:}

1. Кожна публікація не англійською мовою супроводжується анотацією англійською мовою обсягом не менш як 1800 знаків (з ключовими словами). Якщо видання не $\epsilon$ повністю українськомовним, кожна публікація не українською мовою супроводжується анотацією українською мовою обсягом не менш як 1800 знаків (з ключовими словами, ураховуючи пропуски).

2. Вимоги до анотацій англійською мовою: інформативність (без загальних слів); змістовність (відображення основного змісту статті та результатів досліджень); застосування термінології, характерної для іноземних спеціальних текстів; єдність термінології в межах анотації; без повторення відомостей, що містяться в заголовку статті.

3. Прізвища авторів статей надаються в одній із прийнятих міжнародних систем транслітерації (з української - відповідно до Постанови Кабінету Міністрів України № 55 від 27.01.2010“Про впорядкування транслітерації українського алфавіту латиницею", з російської - відповідно до "Системы транслитерации Библиотеки конгресса США"). Зазначення прізвища в різних системах транслітерації призводить до створення в базі даних різних профілів (ідентифікаторів) одного автора.

4. Для повного й коректного створення профілю автора дуже важливо зазначити місце його роботи. Дані про публікації автора використовуються для отримання повної інформації щодо наукової діяльності організацій і загалом країни. Застосування в статті офіційної, без скорочень, назви організації англійською мовою запобігатиме втраті статей у системі аналізу організацій та авторів. Бажано вказати в назві організації відомство, якому вона підпорядковується.

5. В аналітичній системі SCOPUS потрібні пристатейні списки використаної літератури латиницею. Можливості SCOPUS дають змогу проводити такі дослідження: за покликаннями оцінювати значення визнання робіт конкретних авторів, науковий рівень журналів, організацій і країн загалом, визначати актуальність наукових напрямів і проблем. Стаття з представленим списком літератури демонструє професійну ерудицію та якісний рівень досліджень її авторів.

6. Правильний опис джерел, на які покликаються автори, $\epsilon$ запорукою того, що цитовану публікацію буде враховано в процесі оцінювання наукової діяльності їі авторів, а отже й організації, регіону, країни. За статистикою цитування журналу визначають його науковий рівень, авторитетність тощо. Тому найважливішими складниками в бібліографічних покликаннях $\epsilon$ прізвища авторів і назви журналів. До опису статті треба вносити імена всіх авторів, не скорочуючи їхньої кількості. Для уникнення неточностей в ідентифікації авторства й визначення персональних метрик (показників) бібліометрії авторам наукових публікацій потрібно використовувати персональні коди ORCID.

7. Для українсько- та російськомовних статей з журналів, збірників, матеріалів конференцій структура бібліографічного опису така: автори (транслітерація), переклад назви статті англійською мовою, назва джерела (транслітерація), вихідні дані, у дужках - мова оригіналу, ідентифікатор DOI.

8. Список використаної літератури (References) для SCOPUS та інших закордонних баз даних наводиться повністю окремим блоком, повторюючи список літератури, що подається українською/ російською мовою, незалежно від того, містяться в ньому чи ні іноземні джерела. Якщо в списку $є$ покликання на іноземні публікації, їх повністю повторюють у списку, який створюють латиницею.

Рукопис статті до редакції автори подають зі своїми підписами. 